DOI

\title{
ПОБІЧНІ РЕАКЦІї У ХВОРИХ НА НЕЕФЕКТИВНО ЛІКОВАНИЙ ВПЕРШЕ ДІАГНОСТОВАНИЙ ТУБЕРКУЛЬОЗ
}

\author{
ФР. М. Шевченко ${ }^{1}$, Ю. В. Просвєтов ${ }^{2}$, Р. М. Ясінський ${ }^{1}$, А. В. Левіч ${ }^{2}$ \\ Запорізький державний медичний університет ${ }^{1}$ \\ ДЗ «Запорізька медична академія післядипломної освіти МОЗ України» 2
}

РЕЗЮМЕ. Метою дослідження стало встановлення структури побічних реакцій (ПР) та особливостей перебігу туберкульозу у хворих на вперше діагностований неефективно лікований туберкульоз, у яких виникли побічні реакції на протитуберкульозні препарати першого ряду. Проаналізовано 60 історій хвороб пацієнтів. Хворих було поділено на 2 групи: з ПР (І група) - 34 пацієнти, без ПР (ІІ група) - 26 хворих. Визначали статистичну значимість відмінностей між групами за допомогою критерію х-квадрат, при кількості випадків менше 20 додатково користувалися правкою Єтса. Для аналізу кількісних показників використовували t-критерій Стьюдента.

Тривалість інтенсивної фази лікування (з урахуванням терапії за 1 і 2 категоріями разом) у хворих, які мали ПР, була більшою: $(188,6 \pm 9,5)$ доз проти $(166,2 \pm 6,1)$ доз пацієнтів II групи $(p<0,05)$, за рахунок її подовження через відсутність конверсії мазка мокротиння або негативну рентгенологічну динаміку.

У 32,4 \% хворих побічні реакції мали клінічні прояви, вимагали відміни протитуберкульозних засобів і не зникали після призначення коригуючої терапії, що призводило до збільшення термінів лікування в інтенсивній фазі на $(22,4 \pm 3,4)$ доз, $p<0,05$.

КЛЮчОВІ СЛОВА: туберкульоз, невдача лікування, побічні реакції.

Вступ. Незважаючи на здобутки сучасної фтизіатрії, відсоток хворих з вперше діагностованим туберкульозом (ВДТБ), які успішно завершили лікування, залишається вкрай незадовільним. За літературними даними, частка хворих з невдачею лікування (НЛТБ) серед пацієнтів із ВДТБ легень сягає 22,6\%, проте тільки 48 \% із них успішно завершують курс лікування $[8,10]$. У Запорізькій області, за даними єдиного реєстру 2015 р., у 11,79 \% хворих із ВДТБ діагностовано НЛТБ.

Окрім негативних соціально-побутових факторів і некомплаєнтності хворих, погана переносимість протитуберкульозних засобів займає провідне місце серед предикторів невдачі лікування хворих на ВДТБ $[1,2,4,6,9,10]$. У 2/3 хворих лікування ВДТБ ускладнюється розвитком різноманітних за тяжкістю та патогенезом побічних реакцій $[3,5]$. ПР є найпоширенішою причиною неповноцінно сформованих схем антимікобактеріальної терапії, часто призводять до переривання лікування, що веде до набуття хіміорезистентності, поширення ії̈ спектра та формування невиліковних форм туберкульозу [1, 2, 5-7]. Існують дані, що розвиток двох чи більше побічних реакцій $є$ фактором, який гальмує припинення бактеріовиділення $[1,9]$. На сьогоднішній день у літературі не визначено структуру побічних реакцій у хворих на НЛТБ, недостатньо вивчений патогенез їх виникнення та тривають пошуки шляхів їх адекватної корекції.

Мета дослідження - встановити структуру побічних реакцій та особливості перебігу туберкульозу у хворих на вперше діагностований не- ефективно лікований туберкульоз, у яких виникли побічні реакції.

Матеріал і методи дослідження. Проведено ретроспективний аналіз 60 історій хвороб пацієнтів, які лікувалися у КУ «Запорізький обласний протитуберкульозний клінічний диспансер» 3ОР 3 01.01.2013 по 31.08.2015 рр. з діагнозом «Невдача лікування» серед пацієнтів із ВДТБ. Оцінювали дані клінічного, рентгенологічного, інструментального, мікроскопічного, бактеріологічного обстежень хворих. Визначали всі побічні реакції, які виникали у пацієнтів протягом курсу лікування.

Хворих поділили на 2 групи: пацієнти, у яких розвинулися ПР (І група), пацієнти, у яких не спостерігались ПР (II група). До І групи увійшли 34 пацієнти: 23 чоловіки (67,6 \%), 11 жінок (32,4\%), середній вік хворих становив $(45,6 \pm 1,9)$ років. До II групи увійшли 26 пацієнтів: 23 чоловіки $(88,5 \%)$ і 3 жінки (11,5 \%), середній вік хворих був $(46,1 \pm 1,8)$ років. Групи достовірно не відрізнялися за віком і статтю.

Статистичну обробку інформації проводили з використанням статистичного пакета ліцензійної програми «STATISTICA® for Windows 6.0» (Stat Soft Inc., № AXXR712 D833214FAN5). Для якісних показників визначали статистичну значимість відмінностей між групами за допомогою критерію $\chi$-квадрат, при кількості випадків менше 20 додатково користувалися правкою Єтса. Для аналізу кількісних показників використовували t-критерій Стьюдента.

Результати і обговорення. Серед клінічних форм у хворих обох груп переважали інфільтративна із засівом і дисемінована обох легень (рис. 1). 


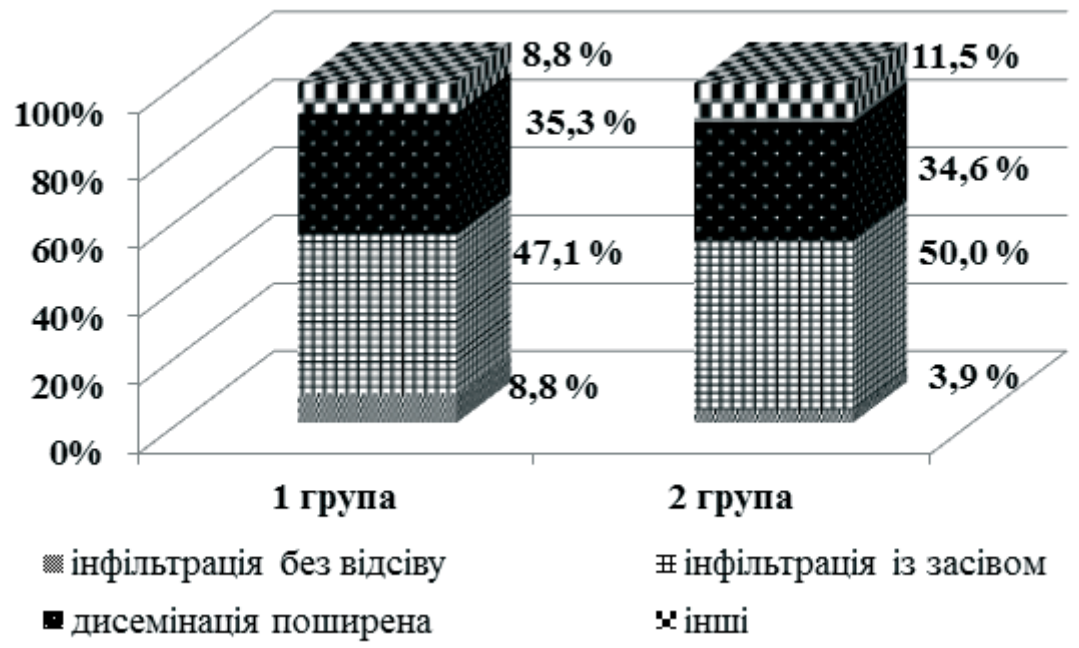

Рис. 1. Клінічні форми туберкульозу легень у групах хворих.

Деструкції у легенях визначалися у 32 пацієнтів $(94,1$ \%) І групи та у всіх хворих II групи. За кількістю деструкцій, їх розмірами та поширеністю у легенях (табл. 1) групи статистично значимо між собою не відрізнялися ( $p>0,05)$.
Порівнюючи кількість хворих із позалегеневим туберкульозним ураженням (ПЗТБ) у групах (табл. 2), визначили, що у пацієнтів І групи ПЗТБ діагностували статистично значимо частіше у 2,3 раза $(p<0,005)$.

Таблиця 1. Поширеність, кількість і розміри деструкцій у групах хворих

\begin{tabular}{|c|c|c|c|c|c|}
\hline \multirow{2}{*}{ Показник } & \multicolumn{2}{|c|}{ I група } & \multicolumn{2}{|c|}{ II група } & \multirow{2}{*}{$\mathrm{P}$} \\
\hline & a6c. & $\%$ & a6c. & $\%$ & \\
\hline Всього & 32 & 100,0 & 26 & 100,0 & $>0,05$ \\
\hline Розміри > 2 см & 27 & 84,4 & 25 & 96,2 & $>0,05$ \\
\hline Розміри $\geq 3$ см & 21 & 65,6 & 21 & 80,8 & $>0,05$ \\
\hline Розміри $\geq 4$ см & 16 & 50,0 & 14 & 53,8 & $>0,05$ \\
\hline Множинні деструкції & 6 & 18,8 & 5 & 19,2 & $>0,05$ \\
\hline Деструкції у обох легенях & 15 & 46,9 & 10 & 38,5 & $>0,05$ \\
\hline
\end{tabular}

Таблиця 2. Поширеність, кількість і розміри деструкцій у групах хворих

\begin{tabular}{|c|c|c|c|c|c|}
\hline \multirow{2}{*}{ Позалегеневі ураження } & \multicolumn{2}{|c|}{ I група } & \multicolumn{2}{|c|}{ II група } & \multirow{2}{*}{$\mathrm{P}$} \\
\hline & a6c. & $\%$ & a6c. & $\%$ & \\
\hline Всього & 14 & 41,2 & 6 & 23,1 & $<0,05$ \\
\hline Бронхи & 10 & 71,4 & 5 & 83,3 & $>0,05$ \\
\hline Гортань & 1 & 7,1 & 1 & 16,7 & $>0,05$ \\
\hline Внутрішньогрудні лімфатичні залози & 1 & 7,1 & 0 & 0 & $>0,05$ \\
\hline Плевра & 2 & 14,4 & 0 & 0 & $>0,05$ \\
\hline
\end{tabular}

У обох групах переважали пацієнти із бактеріовиділенням: 33 особи у І групі (97,1\%), 26 осіб (100\%) - у ІІ групі. Масивне бактеріовиділення визначалося у 23 осіб І групи (69,7 \%) та у 12 (84,6 \%) - II групи. Більше ніж 1/3 хворих обох груп мали резистентність до лікарських засобів 1 ряду: 13 пацієнтів (39,4 \%) І групи та 12 (46,2 \%) - II групи.

При аналізі лабораторних показників (табл. 3) встановлено, що статистично значимо за показниками клінічного аналізу крові та показниками функції печінки хворі обох груп не відрізнялися, р>0,05.
У пацієнтів I групи ПР були наступними: у 25 випадках (73,5 \%) - зростання рівнів трансаміназ, алергічний дерматит - у 7 осіб (20,6 \%), артралгія - у 3 хворих (8,8 \%), судоми та гіпертермія - по 1 випадку (2,9\%). Встановлено, що ПР після вживання піразинаміду виникли у 30 випадках, рифампіцину - у 5 випадках, ізоніазиду та етамбутолу - по 1 випадку. Були випадки виникнення кількох ПР у одного пацієнта, всього зареєстровано 37 ПР у 34 хворих. У 23 осіб ПР не мали клінічних проявів, не вимагали відміни препаратів і зникали після призначення симптоматичної 
Огляди літератури, оригінальні дослідження, погляд на проблему терапії, у 11 пацієнтів (32,4 \%) ПР були клінічно виражені або не зникали після коригуючої тера-

пії, потребували відміни лікарських протитуберкульозних засобів.

Таблиця 3. Лабораторні показники у групах хворих

\begin{tabular}{|c|c|c|c|}
\hline Показники & 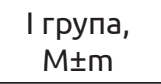 & 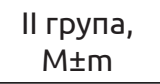 & $p$ \\
\hline Гемоглобін, г/л & $122,2 \pm 4,3$ & $122,5 \pm 4,1$ & $>0,05$ \\
\hline Еритроцити, ×1012/л & $3,8 \pm 0,1$ & $3,9 \pm 0,1$ & $>0,05$ \\
\hline Лейкоцити, ×109/л & $8,7 \pm 0,5$ & $8,3 \pm 0,4$ & $>0,05$ \\
\hline ШОЕ, мм/год & $34,8 \pm 3,6$ & $41,2 \pm 3,5$ & $>0,05$ \\
\hline Паличкоядерні нейтрофіли, \% & $7,7 \pm 0,9$ & $7,8 \pm 0,8$ & $>0,05$ \\
\hline Сегментоядерні нейтрофіли, \% & $58,9 \pm 2,5$ & $61,0 \pm 1,8$ & $>0,05$ \\
\hline Еозинофіли, \% & $1,8 \pm 0,5$ & $1,9 \pm 0,6$ & $>0,05$ \\
\hline Лімфоцити, \% & $22,7 \pm 1,8$ & $20,8 \pm 1,3$ & $>0,05$ \\
\hline Моноцити, \% & $7,6 \pm 0,7$ & $7,8 \pm 0,9$ & $>0,05$ \\
\hline Білірубін, мкмоль/л & $11,3 \pm 0,6$ & $10,5 \pm 0,7$ & $>0,05$ \\
\hline АЛТ, мкмоль/год×мл & $0,43 \pm 0,06$ & $0,29 \pm 0,08$ & $>0,05$ \\
\hline АСТ, мкмоль/год×мл & $0,44 \pm 0,06$ & $0,33 \pm 0,09$ & $>0,05$ \\
\hline
\end{tabular}

Тривалість інтенсивної фази лікування (з урахуванням терапії за 1 і 2 категоріями разом) у хворих, які мали ПР, була більшою: $(188,6 \pm 9,5)$ доз проти $(166,2 \pm 6,1)$ доз у пацієнтів II групи, $p<0,05$, за рахунок ії подовження через відсутність конверсії мазка мокротиння або негативну рентгенологічну динаміку.

Висновки. У хворих на неефективно лікований вперше діагностований туберкульоз переважають побічні реакції у вигляді зростання рівнів трансаміназ, які у переважної кількості пацієнтів вдається усунути шляхом симптоматичної терапії. За клініко-рентгенологічними, бактеріологічними та лабораторними показниками перебіг захворювання у пацієнтів із неефективно лікованим вперше діагностованим туберкульозом із побічними реакціями не відрізнявся від перебігу хвороби у осіб контрольної групи, окрім того, що у них частіше визначався також позалегеневий туберкульоз. У 32,4 \% хворих побічні реакції мали клінічні прояви, вимагали відміни протитуберкульозних засобів і не зникали після призначення симптоматичної терапії, що призводило до збільшення термінів лікування в інтенсивній фазі на $(22,4 \pm 3,4)$ доз, $\mathrm{p}<0,05$.

Перспективи подальших досліджень. 3 метою встановлення патогенетичних механізмів виникнення побічних реакцій у хворих на неефективно лікований вперше діагностований туберкульоз виникає необхідність вивчення біохімічних та імунологічних зрушень у таких пацієнтів.

\section{ЛІТЕРАТУРА}

1. Ефективність лікування хворих на вперше діагностований туберкульоз та чинники, які погіршують її в сучасних умовах / В. М. Мельник, І. О. Новожилова, В. Г. Матусевич, Л. В. Ареф'єва // Український пульмонологічний журнал. - 2008. - № 2. - С. 55-59.

2. Мордык А. В. Частота и патогенез неблагоприятных побочных реакций на противотуберкулезные препараты / А. В. Мордык // Вестник современной клинической медицины. - 2010. - Вып. 1, Т. 3. - С. 17.

3. Просвєтов Ю. В. Побічна дія протитуберкульозних препаратів алергічного характеру у хворих на туберкульоз легень (гормонально-метаболічні й імунні аспекти патогенезу, профілактики та лікування) : автореф. дис. д-ра мед. наук. - К., 2009. - 31 с.

4. Свистунова В. А. Анализ факторов, определяющих приверженность к лечению больных туберкулезом / В. А. Свистунова // Бюллетень медицинских Интернет-конференций (ISSN 2224-6150) 2013. - Т. 3, № 2. C. 415 .

5. Побічні реакції протитуберкульозних препаратів у процесі оцінки наслідків лікування хворих на туберкульоз / Ю. І. Фещенко, С. О. Черенько, В. П. Яйченя [та ін.] // Туберкульоз, легеневі хвороби, ВІЛ-інфекція. 2014. - № 4. - С. 13-20.

6. Влияние побочных эффектов противотуберкулезных препаратов на исходы лечения пациентов с множественно лекарственно-устойчивым туберкулезом легких, пролеченных по схемам программы DOTSPLUS / Д. Ю. Щегерцов, Е. В. Некрасов, Г. В. Янова [и др.] // Бюллетень сибирской медицины. - 2011. - № 1. C. $132-136$.

7. Alomar M. J. Factors affecting the development of adverse drug reactions (Review article) / M. J. Alomar // Saudi Pharmaceutical Journal. - 2014. - № 22. - P. 83-94.

8. Prevalence of treatment failure among pulmonary tuberculosis patients in Federal Medical Centre, Gombe, Northeastern Nigeria [Electronic resource] / Y. B. Jibrin, A. B. Ali, S. T. Saad, P. M. Kolo // International scholarly re- 
Огляди літератури, оригінальні дослідження, погляд на проблему

search notices. Infectious disease. - 2013. Mode of access:

http://dx.doi.org/10.5402/2013/461704.

9. Predictors of treatment failure among pulmonary tuberculosis patients in Mulago hospital, Uganda / E. Namukwaya, F. N. Nakwagala, F. Mulekya [et al.] // African
Health Sciences. - 2011. - № 11. - P. 105-111.

10. Risk factors for tuberculosis treatment failure, default, or relapse and outcomes of retreatment in Morocco / K. E. Dooley, O. Lahlou, I. Ghali [et al.] // BMC public health. - 2011. - Vol. 11. - P. 140.

\title{
ADVERSE DRUG REACTIONS IN PATIENTS WITH NEWLY DIAGNOSED TREATMENT FAILURE TUBERCULOSIS
}

\author{
@R. M. Shevchenko', Yu. V. Prosvietov', R. M. Yasinskyi', A. V. Levich'² \\ Zaporizhian State Medical University ${ }^{1}$ \\ Zaporizhian Medical Academy of Postgraduate Education²
}

SUMMARY. The aim of the study was to establish structure of adverse reactions (AR) and peculiarities of tuberculosis in patients with newly diagnosed treatment failure tuberculosis, which had adverse reactions to antituberculosis drugs of first group. To achieve the aim we analyzed 60 cases of patients. Patients were divided into 2 groups: AR (I group) 34 patients without AR (second group), that included 26 patients. We determined the statistical significance of differences between groups using the criterion of "x-squared", while the number of cases, that used was less than 20 we additional used Yates' correction for continuity. For quantitative - using the Student t-test.

The duration of the intensive phase of treatment (including treatment for categories 1 and 2 together) in patients who have AR was more: (188.6 \pm 9.5$)$ doses in I group in comparison with $(166.2 \pm 6.1)$ doses in group II ( $<<0.05)$, due to its extension due to lack of conversion of sputum smear or negative radiological dynamics.

$32.4 \%$ of patients had adverse reactions with clinical manifestations, that caused the abolition of anti-tuberculosis drugs and did not disappear after administration of corrective therapy. All these led to increase of terms of treatment in the intensive phase at (22.4 \pm 3.4$)$ doses $p<0.05$.

KEY WORDS: tuberculosis, failure of treatment, adverse drug reactions. 